

\title{
НАТУРНІ ВИПРОБУВАННЯ КОСОГО В ПААНІ ЗАЛІЗОБЕТОННОГО МОСТА
}

\section{АНОТАЦІЯ}

Залізобетонні мости 3 косим перетином перепони (косі в плані мости) з балковими перехресно-ребристими прольотними будовами мають характерні конструктивні відмінності в компонуванні балкової клітки порівняно 3 прямими. Оскільки теоретичне створення їх розрахункової моделі є доволі складним навіть при виконанні у пружній постановці, то для практичних потреб цю задачу розв'язували не теоретично, а шляхом проведення їх натурних випробувань що, як правило, дає вичерпну відповідь на технічний стан та характер просторової роботи випробовуваних типів прольотних будов. Дослідження роботи перехресно-ребристих конструкцій $є$ актуальне і необхідне.

Проведено випробування під час реконструкції косих в плані прольотних будов міського шляхопроводу по вул. Городоцькій у м. Аьвові. Як об'єкт інфраструктури вулиці загальноміського значення для приведення його експлуатаційних показників до вимог чинних норм була необхідна його реконструкція 3 розширенням габариту мостового полотна, підсиленням і ремонтом пошкоджених елементів та ліквідацією дефектів. 3 метою встановлення можливостей використання існуючих прольотних будов в реконструйованій споруді і проводилися представлені випробування. Випробовували існуючі прольотні будови крайнього і середнього прольотів, що конструктивно відрізнялись між собою косою (крайній) і прямою (середній) орієнтацією діафрагм. Метою досліджень було визначення особливостей характеру просторової роботи, розподілу зусиль між балками, перевірка дійсної і прийнятої в розрахунках моделі і схеми просторової роботи прольотних будов.

Випробування підтвердили можливість вико- ристання існуючих прольотних будов крайнього і середнього прольотів із демонтованими неремонтопридатними крайніми балками при реконструкції моста за умови їх підсилення зміною статичної схеми, ліквідації наявних дефектів i пошкоджень та повної заміни комплексу їздового полотна і тротуарів.

КАЮЧОВІ СЛОВА: косий в плані міст, косі і прямі діафрагми, розрахункова модель, випробування, розподіл зусиль.

\section{НАТУРНЫЕ ИСПЫТАНИЯ КОСОГО В ПААНЕ ЖЕЛЕЗОБЕТОННОГО МОСТА}

ГОРБАЧЕВСКИЙ Р.Р. Инж., Институт строительства и инженерии окружающей среды, Национальный университет «Львовская политехника»,

г. Аьвов, Украина,

e-mail: gororogen@gmail.com,

тел.: + 38 (063) 418-30-39,

ORCID: 0000-0001-7713-5331

РУБАХА М.В. Зам. нач. отдела, Служба автомобильных дорог во Аьвовской области,

г. Аьвов, Украина,

e-mail: TekhKontrolSAD@gmail.com,

тел.: + 38 (067) 670-66-99,

ORCID: 0000-0002-9719-2007

\section{АННОТАЦИЯ}

Железобетонные мосты с косым пересечением преграды (косые в плане мосты) с балочными перекрестно-ребристыми пролетными строениями имеют характерные конструктивные отличия в компоновке балочной клетки по сравнению с прямыми. Поскольку теоретическое создание их расчетной модели довольно сложное даже при выпол- 


\section{WLA 1 Mah}

нении в упругой постановке, то для практических нужд эту задача решали не теоретически, а путем натурных испытаний которые, как правило, дают исчерпывающий ответ на техническое состояние и характер пространственной работы испытуемых типов пролетных строений. Исследование работы перекрестно-ребристых конструкций является актуальным и необходимым.

Проведены испытания во время реконструкции косых в плане пролетных строений городского путепровода по ул. Городоцкой в г. Аьвове. Как объект инфраструктуры улицы общегородского значения для приведения его эксплуатационных показателей требованиям действующих норм была необходима его реконструкция с расширением габарита мостового полотна, усилением и ремонтом поврежденных элементов и ликвидацией дефектов. С целью установления возможностей использования существующих пролетных строений в реконструированном здании и проводилось представленные испытание. Испытывали существующие пролетные строения крайнего и среднего пролетов, которые конструктивно отличались между собой косой (крайний) и прямой (средний) ориентацией диафрагм. Целью было исследование особенностей характера пространственной работы, распределения усилий между балками, проверка действительной и принятой в расчетах модели и схемы пространственной работы пролетных строений.

Испытания подтвердили возможность использования существующих пролетных строений крайнего и среднего пролетов с демонтированными неремонтопригодными крайними балками при реконструкции моста при условии их усиления изменением статической схемы, ликвидации имеющихся дефектов и повреждений и полной замены комплекса ездового полотна и тротуаров.

КЛЮЧЕВЫЕ СЛОВА: косой в плане мост, косые и прямые диафрагмы, расчетная модель, испытания, распределение усилий.

\section{FULL-SCALE TESTS OF A SKEW IN PLAN REINFORGED CONGRETE BRIDGE}

HORBACHEVSKYI R.R. Eng., Institute of Building and Environmental Engineering, Lviv Polytechnic National University,

Lviv, Ukraine,

e-mail: gororogen@gmail.com,

tel.: + 38 (063) 418-30-39,

ORCID: 0000-0001-7713-5331

RUBAKHA M.V. Dep. Head of Department, Lviv Road Service,

Lviv, Ukraine,

e-mail: TekhKontrolSAD@gmail.com,

tel.: (067) 670-66-99,

ORCID: 0000-0002-9719-2007

\section{ABSTRACT}

Reinforced concrete bridges with skew crossbarriers (the skew in plan bridges) with beam crossribbed span structures have characteristic constructive differences in the layout the floor beam systems compared to straight systems. The theoretical creation of their calculation model is rather complicated, even when performed in an elastic setting, therefore, for practical purposes, this problem is solved not theoretically, but by conducting their full-scale tests, which, as a rule, give an exhaustive answer to the technical condition and the nature of the spatial performance of the tested types of span structures. The research of the cross-ribbed structures behavior is actual and necessary.

Tests were conducted during the reconstruction of the skew in plan span structures of the city overpass on Gorodotska street in Lviv. The overpass is an infrastructure object at the street of citywide importance, so to bring its performance parameters to the requirements of the current codes it was necessary to reconstruct it with the expansion of the deck of the bridge, to strengthen and repair damaged elements and to eliminate defects. The tests were conducted for purpose of determining the possibilities of using existing span structures in a reconstructed facility. So, existing span structures of the outermost and middle spans, which differed constructively from each other by the skew (outermost) and straight (middle) orientation of the diaphragms, were tested. The purpose was to research the actual nature of spatial performance, the distribution of efforts between beams, and the validation of actual and accepted in the calculations of the model and schemes spatial behavior of span structures.

The tests confirmed the possibility of using the existing span structures of the outmost and middle spans with nonrepairable outmost girders removed during bridge reconstruction, on condition that they are strengthened by changing the static scheme, eliminating existing defects and damages, and completely replacing the bridge deck and sidewalks.

KEY WORDS: skew in plan bridge, skew and straight diaphragms, calculation model, tests, efforts distribution

\section{ВСТУП. ПОСТАНОВКА ПРОБАЕМИ. МЕТА РОБОТИ}

Залізобетонні мости з косим перетином перепони (косі в плані мости) з балковими перехресноребристими прольотними будовами мають характерні конструктивні відмінності в компонуванні балкової клітки порівняно з прямими. Зокрема, це зміщення в плані головних балок на опори, а також коса або пряма орієнтація поперечних балок (діафрагм), що об'єднують головні балки поперек прольоту в перехресно-ребристу балкову клітку.

Просторовий розрахунок цих прольотних будов для визначення в їх елементах зусиль від зовнішніх 


\section{und 1 Math}

навантажень вважають однією із складних задач будівельної механіки, що до сьогодні не має достатньо придатного для практичних інженерних розрахунків розв'язання. Загальновідомі методи розрахунку, що застосовують у практиці проектування прямих прольотних будов, не в повній мірі відповідають реальній роботі косих в плані прольотних будов $[1,8,11,13]$.

У першу чергу це стосується косих прольотних будов із прямою орієнтацією діафрагм, у яких на приопорних ділянках є кутові діафрагми меншої довжини, ніж у середній частині прольоту, де їх довжина відповідає довжині діафрагм прямих мостів. Короткі кутові приопорні діафрагми, порівняно з прольотними, мають більшу погонну жорсткість, тому в косій балковій просторовій перехресно-ребристій системі створюють додаткові пружні опори для однієї-двох крайніх балок, зменшуючи їх робочий прольот i, відповідно, збільшуючи несучу здатність і жорсткість. Таким чином, саме наявність коротких кутових діафрагм і зумовлюе основну відмінність статичної роботи косих прольотних будов із прямими діафрагмами порівняно 3 аналогічними прямими i косими 3 косими діафрагмами. Хоча можна припустити, що і для цього типу косих мостів зміщення поздовжніх балок на опорах відносно кута косини, при однаковій довжині всіх косо орієнтованих діафрагм, повинно (хоча і в меншій мірі) впливати на статичну роботу і просторовий розподіл зусиль у косій перехресно-ребристій системі.

Оскільки теоретичне створення їх розрахункової моделі є доволі складним навіть при розв'язанні у пружній постановці, у більшості випадків для практичних потреб цю задачу вирішують не теоретично, а шляхом проведення їх натурних випробувань, що, як правило, дає вичерпну відповідь стосовно технічного стану та характеру просторової роботи випробовуваних типів прольотних будов.

Такі випробування проведені під час реконструкції косих у плані прольотних будов міського шляхопроводу по вул. Городоцькій у м. Аьвові. Випробовували існуючі прольотні будови крайнього (К) і середнього (C) прольотів, що конструктивно відрізнялись між собою косою (крайній) і прямою (середній) орієнтаціями діафрагм. Метою досліджень було визначення дійсного характеру просторової роботи, розподілу зусиль між балками, перевірка дійсної і прийнятої в розрахунках моделі і схеми просторової роботи прольотних будов.

Результати випробувань, проведених у Галузевій науково-дослідній лабораторії № 88 Національного університету «Львівська політехніка», представлені у статті.

\section{КОНСТРУКЦІЯ ІСНУЮЧОГО ШІЯЯХОПРОВОДУ}

За конструктивною схемою шляхопровід балковий, розрізний, трьохпрольотний за схемою
11,4+18,6+11,4 м, загальною довжиною 41,4 м і габаритом мостового полотна $\Gamma-10,5+2 \times 0,9$ м (рис. 1). Перетин шляхопроводу з залізничною колією косий під кутом 70. Профіль шляхопроводу і підходів - на випуклій кривій.

Прольотні будови перехресно-ребристі, індивідуального проектування з прив'язкою основних конструктивних рішень до типового проекту ТП вип. 56 [5, 7, 12] у поперечному перерізі зібрані 3 10-ти збірних залізобетонних балок таврового профілю 3 кроком поперек прольоту 1,4 м. Балки об'єднані між собою в просторову перехресноребристу систему прольотної будови поперечними діафрагмами, розташованими вздовж прольотів 3 кроком 2,7 м шляхом зварювання вставних трикутних блоків діафрагм до закладних деталей в ребрах балок - в крайніх прольотах (рис. 1, в) і зварюванням півдіафрагм суміжних балок верхніми i нижніми металевими накладками в середньому прольоті (рис. 1, г). Тип армування балок виконаний за аналогією з ТП вип. 56 двома плоскими зварними каркасами із розташуванням поздовжньої робочої арматури періодичного профілю Ø 32 мм в 4-5 рядів по висоті без зазорів між ними.

Берегові опори шляхопроводу обсипні, полегшеного типу 3 однорядних залізобетонних забивних паль, об'єднаних зверху масивною монолітною залізобетонною насадкою з шафовою стіною і зворотними відкрилками. Проміжні опори скомпоновані 3 двох окремих, двостійкових П-подібних рам, стійки яких мають двотавровий переріз і об'єднані між собою збірним залізобетонним ригелем прямокутного перерізу $145 \times 60$ см. Між двома частинами опори по осі моста в межах висоти ригеля влаштований деформаційний шов. Внизу стійки опор жорстко защемлені у підколонниках стаканного типу, монолітно об'єднаних з суцільною залізобетонною плитою фундаменту.

За останні десятиліття експлуатації у зв'язку 3 погіршенням експлуатаційного стану шляхопровід неодноразово обстежували. Загальний висновок за їх результатами за характером виявлених дефектів і пошкоджень за вимогами чинних норм $[3,4]$ експлуатаційний стан шляхопроводу визнаний як непридатний до нормальної експлуатації в першу чергу через невідповідність експлуатаційним вимогам за пропускною здатністю (недостатній габарит мостового полотна), вантажопідйомністю, довговічністю і надійністю, а також безпекою та комфортністю руху. Як об'єкт інфраструктури вулиці загальноміського значення для приведення експлуатаційних показників шляхопроводу до вимог [2] необхідна його реконструкція 3 розширенням габариту мостового полотна, підсиленням і ремонтом пошкоджених елементів та ліквідацією дефектів. 3 метою встановлення можливостей використання існуючих прольотних будов у реконструйованій споруді і проведені представлені випробування. 


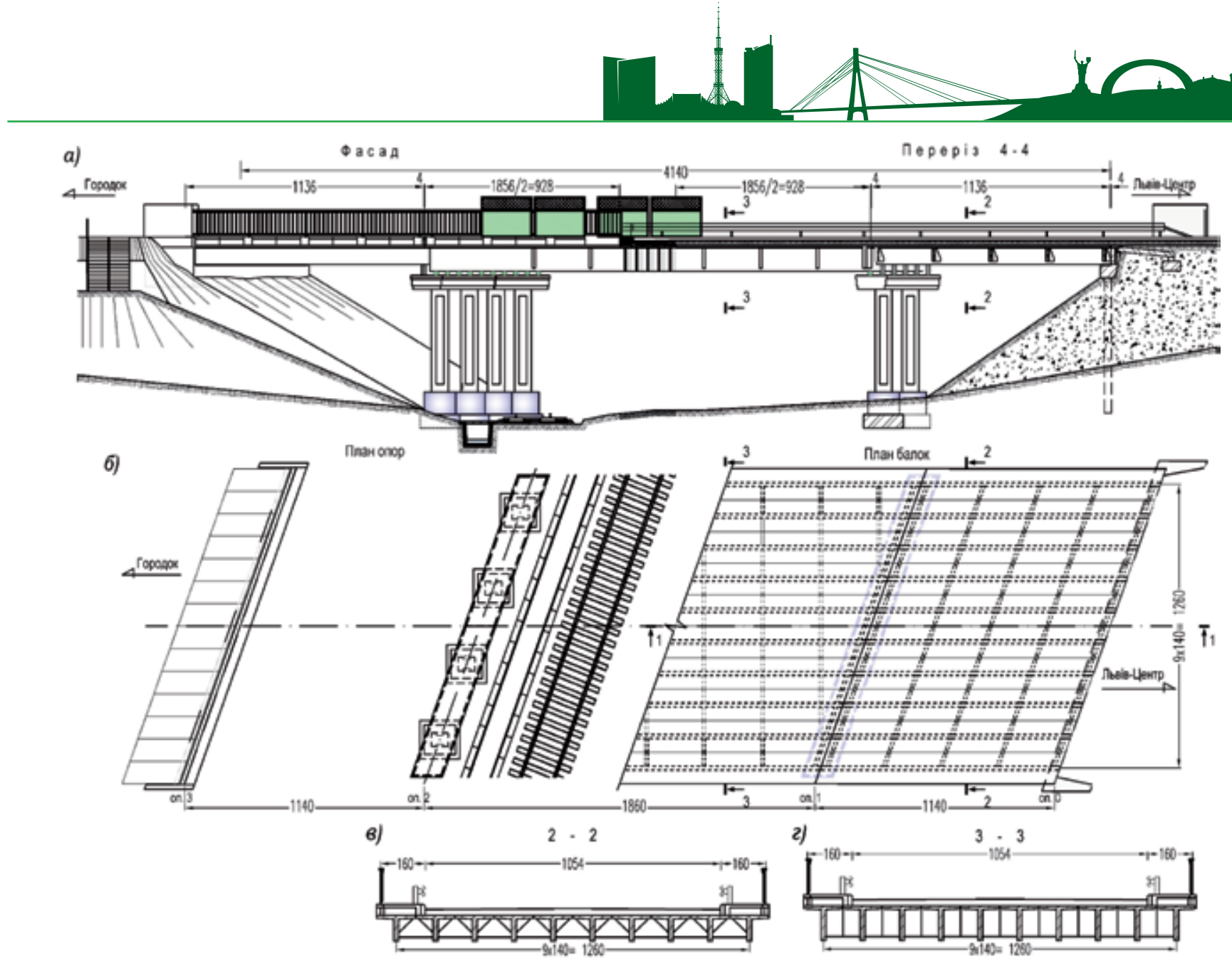

Рис. 1. Конструкція існуючого шляхопроводу. а- фасад і поздовжній переріз; б - план; в, г - поперечні перерізи крайнього і середнього прольотів

\section{ВИПРОБУВАННЯ ПРОАЬОТНИХ БУДОВ ТА ÏХ РЕЗУАЬТАТИ}

Випробовували існуючі прольотні будови крайнього і середнього прольотів, оскільки їх конструкція і способи об'єднання балок поперек прольоту були різними. Випробування проводили під час виконання робіт із реконструкції моста після демонтажу правосторонніх крайніх балок і видалення всіх елементів мостового полотна (крім лівосторонніх тротуарних конструкцій), тобто при мінімальному постійному навантаженні - лише від власної ваги балок.

Для випробувань використовували тимчасове рухоме навантаження з однієї або двох колон навантажених великовагових автомобілів-самоскидів двох марок - два автомобілі КрАЗ (тиск на передню вісь 45,5 кН, на задні вісі візка по 92,3 кН) та два автомобілі КамАЗ (тиск на передню вісь 44,7 кН, на задні вісі візка по 73,5 кН). Схеми розташування на прольотних будовах випробувального навантаження зрозумілі з рис. 2, а також описані в [5].

Навантаження здійснювали ступенево, встановлюючи послідовно за прийнятими схемами в одну колону спочатку один автомобіль КрАЗ (схеми Іа, IIa), потім впритул до нього заднім бортом другий КамАЗ (схеми I6, IIб) і на третьому ступені другу колону 3 двох автомобілів КрАЗ і КамАЗ впритул до першої (схеми Ів, ІІв) з відповідним зміщенням внаслідок косини прольотних будов найбільш навантажених задніх осей на вершину і максимальні ординати також відповідно зміщеної лінії згинального моменту. Вимірювання прогинів балок на кожному ступені навантаження дало можливість одержати залежності прогинів від величини згинальних моментів $f-M$. Прогини вимірювали механічними прогиномірами 6ПАО з ціною поділки 0,01 мм.

Результатом випробувань є прогини балок в середині прольоту, а також визначена за ними, згідно рекомендацій і обгрунтування робіт [6, 9-11], основна характеристика навантажувального ефекту балок - коефіцієнт поперечного розподілу згинальних моментів (КПРМ), що за фізичним змістом відображає частку силової дії, що передається на кожну балку. Залежності розподілу прогинів і КПРМ між балками поперек прольоту і характеризують просторову роботу прольотної будови під навантаженням. Вони представлені у вигляді епюр розподілу між балками поперек крайнього (рис. 3 А) і середнього (рис. 3 Б) прольотів з врахуванням їх косини для схем навантаження I - a, б, в (рис. 3 A) і схем навантаження II-a, б, в (рис. 3 Б).

Закон зміни прогинів балок за всіх схем позацентрового (одностороннього) навантаження існуючих прольотних будов явно виражений нелінійний, що свідчить про просторовий характер роботи (тобто розподіл вузлових зусиль уздовж і поперек прольоту) залізобетонних перехресно-ребристих балкових прольотних будов із співвідношенням довжини прольоту $L$ до ширини між крайніми балками $B L / B<2$, що 6 характерним для крайнього про- 

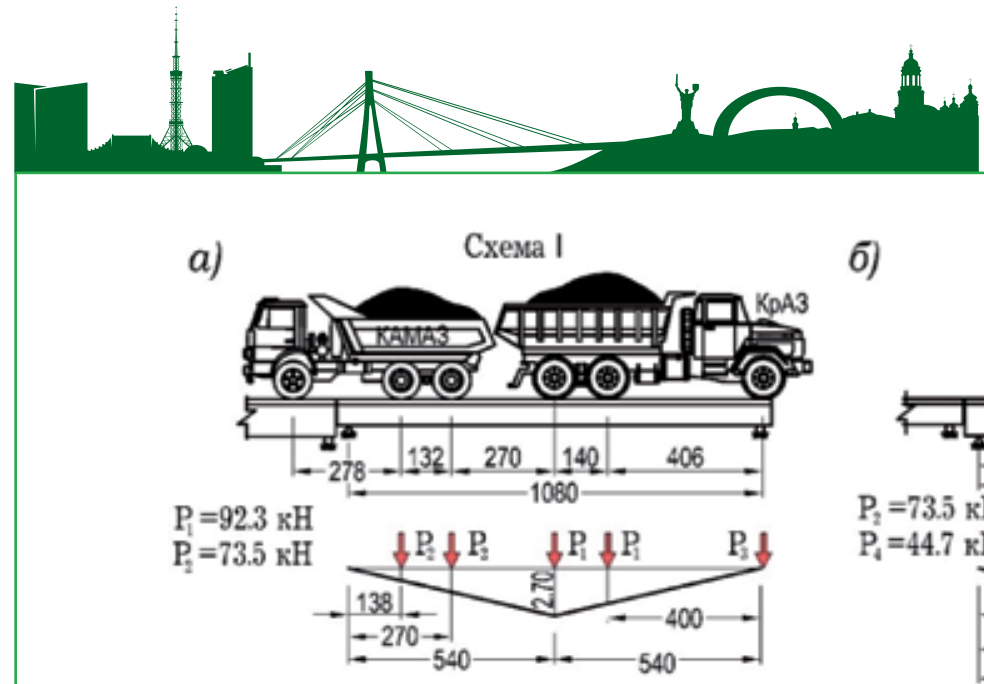

б)

Cxema II
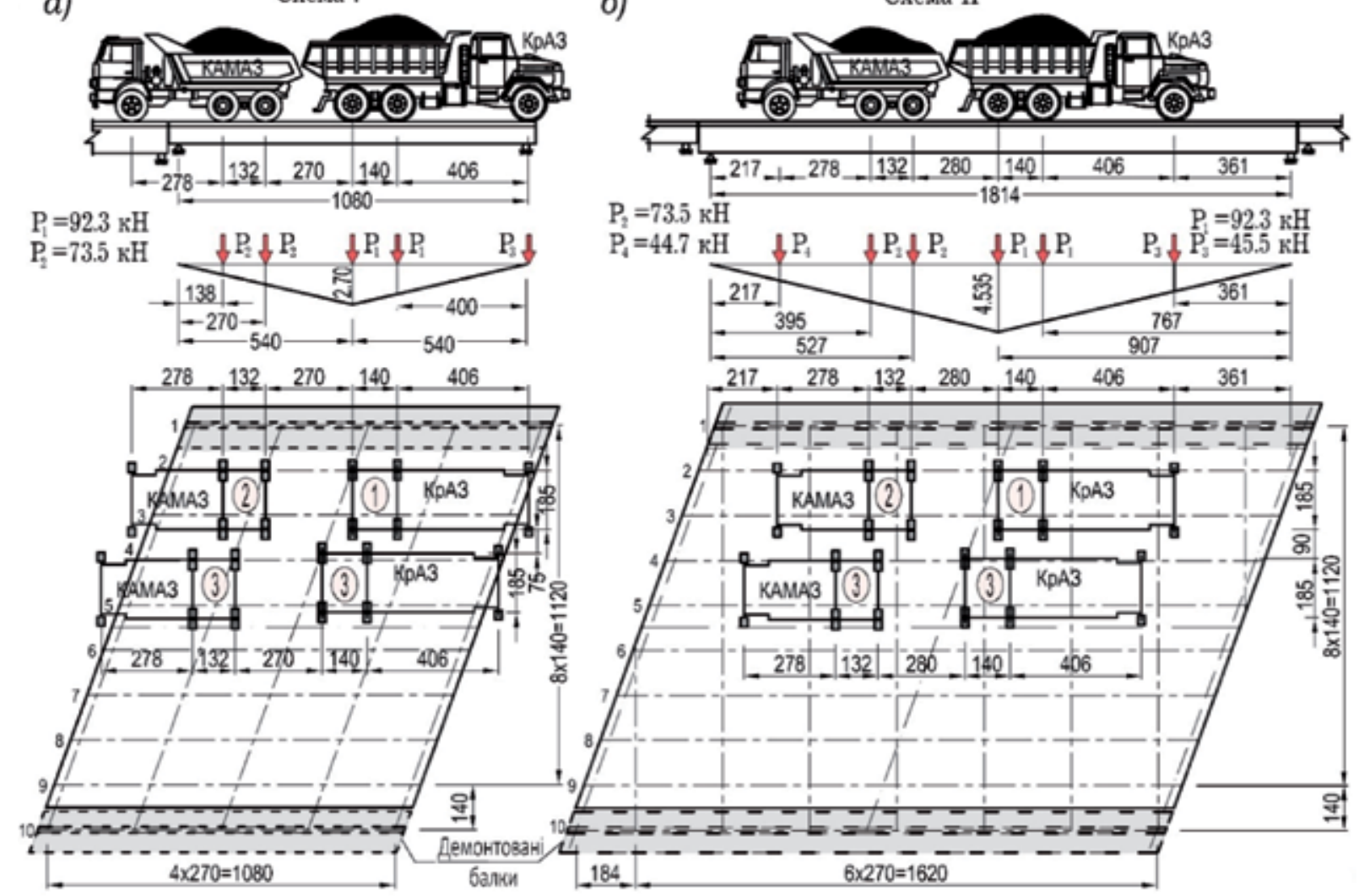

Рис. 2. Схеми навантажень прольотних будов крайнього (а) I-a, б, в і середнього (б) II-а, б, в прольотів, де: а-1; б-1, 2; в-1, 2, 3

льоту з косими діафрагмами. Нелінійний розподіл прогинів між балками та значно менший прогин крайньої балки порівняно $з$ проміжними, в середньому прольоті, який також має співвідношення $L / B<2$ крім того можна пояснити наявністю в косій прольотній будові прямих поперечних діафрагм, що на кутових ділянках відіграють роль пружних проміжних опор, збільшуючи погонну жорсткість крайніх балок. Проблему впливу напрямку поперечних діафрагм (косі чи прямі) на просторову роботу і жорсткість поперечника косих прольотних будов вивчено недостатньо і тому було передбачено проведення спеціальних експериментальних і теоретичних досліджень.

При позацентровому навантаженні прольотної будови крайнього прольоту двома колонами автомобілів із максимальним їх зміщенням до крайньої балки за досягнутого рівня навантаженості найбільший прогин 6,48 мм мала четверта від краю балка (рис. 3 А, а). Відносно розрахункового прольоту цієї балки $L_{0 I}=11,1$ м прогин найбільш навантаженої четвертої балки становить $f / L_{01}=1 / 1713$ при допустимому згідно з вимогами [2] пружному прогинові балки від короткочасних навантажень 1/400 розрахункового прольоту, що в абсолютній величині складає $[f]=1 / 400 \cdot 1110=2,78$ см, тобто фактичний виміряний під час випробувань прогин цієї балки виявився у 4,3 рази меншим допустимого. Це свідчить про значний запас вертикальної жорсткості існуючих балок і можливість сприйняття ними значно більших наван- тажень, ніж досягнуті при випробуваннях.

При максимально досягнутому навантаженні (схема II-в - дві колони автомобілів) найбільший прогин -12,33 мм, як і для крайнього прольоту, мала четверта балка (рис. 3 Б, а).

Відносно розрахункового прольоту $L_{02}=18,14$ м прогин цієї балки становить $f / L_{02}==1 / 1471$ при допустимому від короткочасних тимчасових навантажень $[f]=1 / 400 \times \times 1814=4,54$ см, тобто виміряний при випробуваннях прогин при досягнутому рівні навантаженості балки був у 3,68 разів менший допустимого. Таким чином балки середнього прольоту також можуть сприймати значно більші навантаження від рівня навантаженості під час випробувань.

У цілому криволінійний розподіл прогинів між балками, максимальне деформування, а, відповідно, і максимальна навантаженість проміжних, а не крайніх, балок цієї прольотної будови свідчить про вплив коротких кутових прямих діафрагм у складі косої в плані прольотної будови на збільшення погонної жорсткості крайніх балок, для яких ці діафрагми є додатковими пружними опорами. Можливо на зменшення загальної жорсткості поперечника прольотної будови впливає також податливість стикових з'єднань півдіафрагм зварюванням закладних деталей металевими накладками (типовий стик півдіафрагм у [12]).

Просторову роботу під навантаженням та встановлення можливих методів перевірочних розрахунків прольотних будов даного типу аналізували також за коефіцієнтами поперечного розподілу згиналь- 


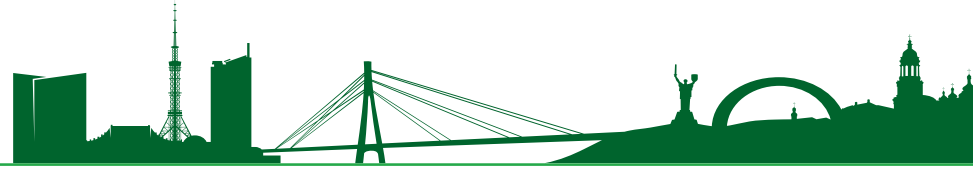

них моментів, що експериментально визначали за виміряними прогинами балок, допускаючи, що розподіл згинальних моментів між балками пропорційний їхнім прогинам (рис. 3 А, Б, б) [6, 9-11].
Знайдені за цією методикою коефіцієнти поперечного розподілу згинальних моментів (КПРМ) i згинальні моменти $M_{i}$ в балках прольотних будов крайнього і середнього прольотів представлені

A)



схема I-а, I-б (середні)

б)

f, MM

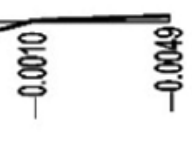

схема I-в

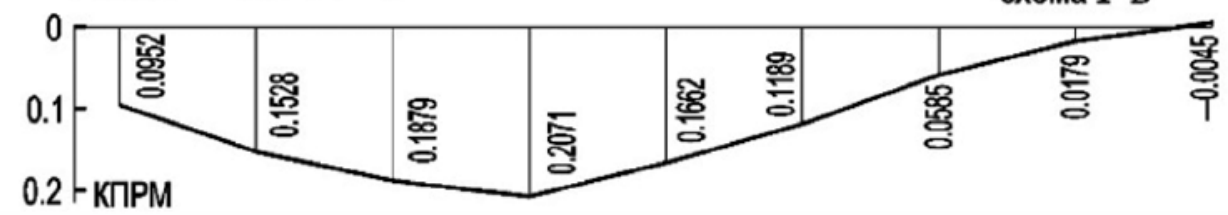

\begin{tabular}{|c|c|c|c|c|c|c|c|c|c|c|}
\hline \multicolumn{2}{|c|}{$\underset{\text { Схема }}{ }$ Балка } & 1 & 2 & 3 & 4 & 5 & 6 & 7 & 8 & 9 \\
\hline \multirow{3}{*}{$\mathrm{I}-\mathrm{a}$} & $\mathrm{f}_{\mathrm{i}, \mathrm{MM}}$ & 1,95 & 2,75 & 2,65 & 2,18 & 1,21 & 0,61 & 0,51 & $-0,01$ & $-0,06$ \\
\hline & $\kappa_{1}$ & 1654 & 0,2332 & 0,2248 & 0,1849 & 0,1026 & 0,0517 & 0,0433 & $-0,008$ & $-0,0051$ \\
\hline & $\mathrm{M}_{\mathrm{i}, \mathrm{r}}$ & 38 & 9 & $\begin{array}{l}97,62 \\
\end{array}$ & 81,7 & 45,62 & 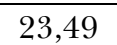 & 19,82 & $-0,44$ & $-2,92$ \\
\hline \multirow{3}{*}{ I- 6} & $\mathrm{f}_{\mathrm{i}, \mathrm{MM}}$ & 2,72 & & 75 & 31 & 79 & $0, \underline{9}$ & 0 , & -0, & $-0,08$ \\
\hline & $\mathrm{K}_{1}^{\prime}$ & 1616 & 2222 & 0,2228 & 1895 & 0,1064 & 0,0559 & 0,0475 & $-0,0012$ & $-0,0048$ \\
\hline & $\mathrm{M}_{\mathrm{i}, \mathrm{I}}$ & & & 64 & 8 & 61,00 & 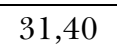 & 26 & -0 , & $\begin{array}{l}-3,91 \\
\end{array}$ \\
\hline$a, 6$ & КПРМ & 535 & 7 & 0,2238 & 0,1872 & 0,1045 & 0,0538 & 0,0454 & $-0,0010$ & $-0,0049$ \\
\hline \multirow{3}{*}{ I-B } & $\mathrm{f}_{\mathrm{i}, \mathrm{MM}}$ & 8 & 4 & 5,88 & 6,48 & 5,20 & 3,72 & 1,8 & 0,56 & $-0,14$ \\
\hline & $\kappa_{1}$ & 0,0952 & 0,1528 & 0,1879 & 0,2071 & 0,1662 & 0,1189 & 0,0585 & 0,0179 & $-0,0045$ \\
\hline & $\mathrm{M}_{\mathrm{i}}$, кНм & 111,38 & 178,63 & 219,72 & 242,14 & 194,62 & 138,93 & 68,42 & 20,90 & $-5,25$ \\
\hline
\end{tabular}

Рис. 3 А. Результати випробувань прольотних будов крайнього (А) прольоту. а - прогини балок; 6 - епюри КПРМ. К1 ; К1'- КПРМ за схемами навантаження I-a і I-6; К2 - КПРМ за схемою навантаження I-в. fi, мм - прогини і-ї балки; Мi, кНм - згинальний момент в і-й балці за відповідних схем навантаження 


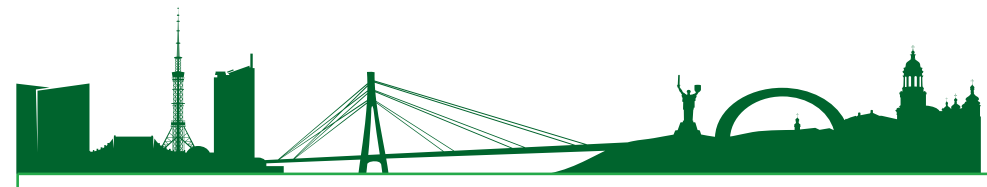

в таблицях на рис. 3, а також у вигляді епюр розподілу між балками поперек прольоту для крайнього (рис. 3 А, б) і для середнього прольотів (рис. 3 Б, б). Причому, КПРМ визначали окремо для однієї (схеми I-a, б; II-а, б) і для двох колон випробувального навантаження (схеми I-в; II-в). Оскільки ці величини визначали за співвідношенням прогинів балок, то і закономірності їх розподіку між балками

Б)
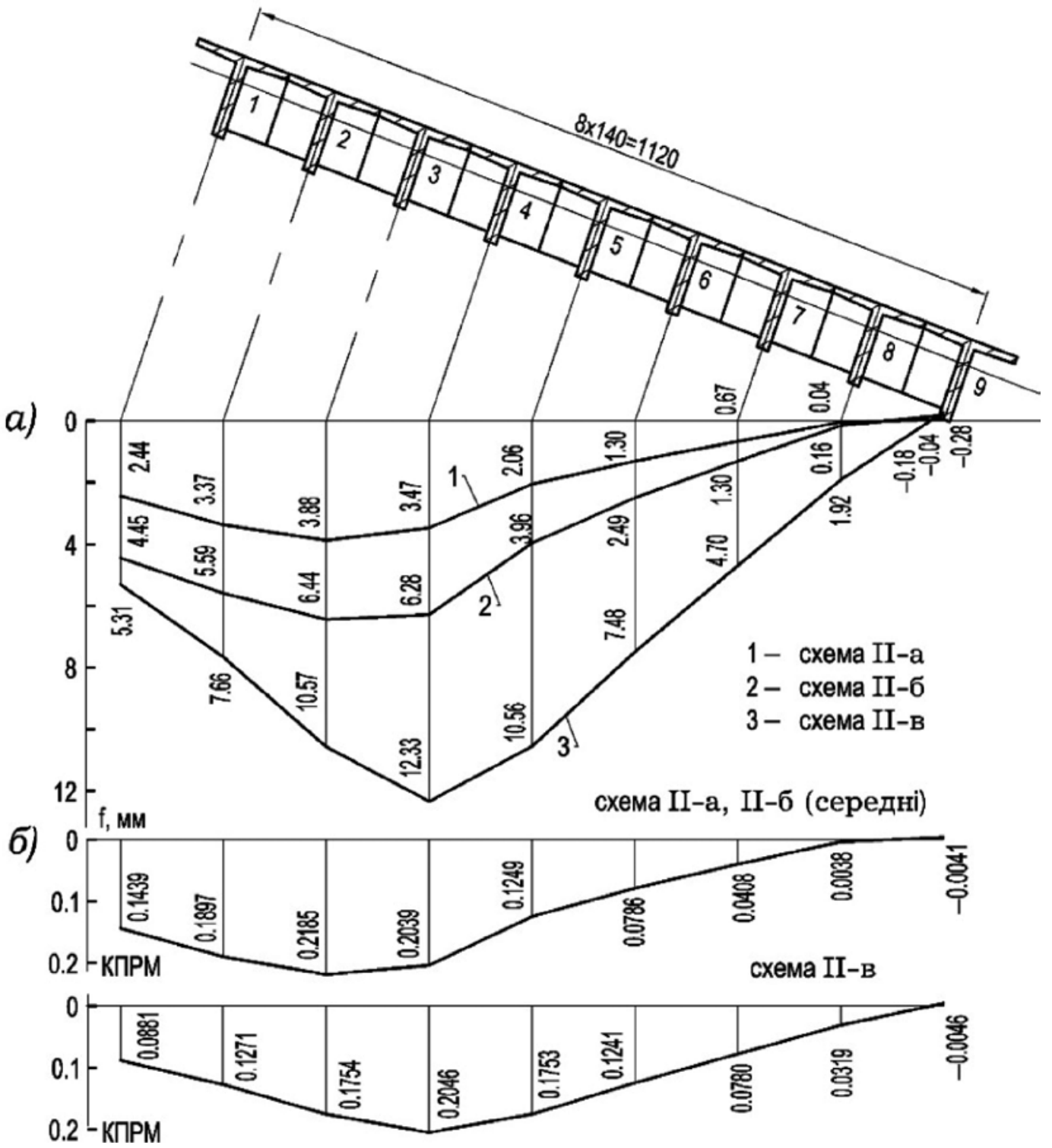

\begin{tabular}{|c|c|c|c|c|c|c|c|c|c|c|}
\hline \multicolumn{2}{|c|}{ Схема } & 1 & 2 & 3 & 4 & 5 & 6 & 7 & 8 & 9 \\
\hline \multirow{3}{*}{ II-a } & $\mathrm{f}_{\mathrm{i}, \mathrm{MM}}$ & 2,44 & 3,37 & 3,88 & 3,47 & 2,06 & 1,3 & 0,67 & 0,04 & $-0,04$ \\
\hline & $\kappa_{2}$ & 0,1419 & 0,1960 & 0,2257 & 0,2019 & 0,1198 & 0,0756 & 0,0390 & 0,0023 & $-0,0023$ \\
\hline & $\mathrm{M}_{\mathrm{i}}, \mathrm{KH} \mathrm{H}_{\mathrm{r}}$ & 123,16 & 162,22 & 186,83 & 174,44 & 106,84 & 67,35 & 1,19 & 3,23 & $-3,5$ \\
\hline \multirow{3}{*}{ II-6 } & $\mathrm{f}_{\mathrm{i}, \mathrm{MM}}$ & 4,45 & 5,59 & 6,44 & 6,28 & 3,96 & 2,49 & 1,30 & 0,16 & $-0,18$ \\
\hline & $\kappa_{2}^{\prime}$ & 0,1459 & 0,1833 & 0,2112 & 0,2060 & 0,1299 & 0,0817 & 0,0426 & 0,0052 & $-0,0059$ \\
\hline & $\mathrm{M}_{\mathrm{i}}$, кНм & 178,98 & 235,74 & 271,51 & 253,50 & 155,25 & 97,87 & 49,68 & 4,72 & $\begin{array}{l}-5,09 \\
\end{array}$ \\
\hline II-a,b & КПРМ & 0,1439 & 0,1897 & 0,2185 & 0,2039 & 0,1249 & 0,0786 & 0,0408 & 0,0038 & $-0,0041$ \\
\hline \multirow{3}{*}{ II-B } & $\mathrm{f}_{\mathrm{i}, \mathrm{MM}}$ & 5,31 & 7,66 & 10,57 & 12,33 & 10,56 & 7,48 & 4,70 & 1,92 & $-0,28$ \\
\hline & $\kappa_{2}$ & 0,0881 & 0,1271 & 0,1754 & 0,2046 & 0,1753 & 0,1241 & 0,0780 & 0,0319 & $-0,0046$ \\
\hline & $\mathrm{M}_{\mathrm{i}}, \mathrm{\kappa Hм}$ & 219,09 & 315,97 & 435,95 & 508,48 & 434,95 & 308,52 & 193,75 & 79,24 & $-11,43$ \\
\hline
\end{tabular}

Рис. 3 Б. Результати випробувань прольотних будов середнього (Б) прольоту. а - прогини балок;

б - епюри КПРМ. К1 ; К1'- КПРМ за схемами навантаження II-a і II-б; К2 - КПРМ за схемою навантаження II-в. fi, мм - прогини і-ї балки; Mi, кНм - згинальний момент в і-й балці 


\section{MULA}

аналогічні закономірностям розподілу прогинів, що наглядно видно з представлених на рис. 3 епюр їх розподілу поперек прольоту.

За одержаними з випробувань розподілом і величинами згинальних моментів в обох випробуваних прольотних будовах при навантаженні їх двома колонами випробувального навантаження (схема I-в і II-в) найбільший навантажувальний ефект мала балка № 4. Максимальний згинальний момент в балці № 4 крайнього прольоту становив $M_{4}=242,14$ кН·м, з урахуванням згинального моменту від власної ваги балки $M_{g, 4}=123,21$ кН·м максимально досягнута під час випробувань навантаженість цієї балки становила $M_{4}^{\text {max }}=242,14+123,21=365,35$ кН·м. Розрахункова несуча здатність балки - $M_{u, 4}=889,0$ кН·м. Таким чином, ступінь навантаженості балки відносно iï несучої здатності становить 41,1 \%, що менше рекомендованої нормами [3] навантаженості - 65\%.

У балці № 4 середнього прольоту максимально досягнутий згинальний момент від двох колон випробувального навантаження становив $M_{4}=508,48$ кН·м, від власної ваги балки $M_{g, 4}=438,06$ кН·м, тобто загальна навантаженість цієї балки складала $M_{4}^{\max }=508,48+438,06=946,54 \kappa \mathrm{\kappa} \cdot \mathbf{м}$ при розрахунковій несучій здатності іiі перерізу в середині прольоту $-M_{u, 4}=2346$ кН·м. Таким чином, ступінь навантаженості цієї балки від випробувального навантаження відносно ії несучої здатності становила 40,4 \%, тобто, як і для балки № 4 крайнього прольоту, була меншою від рекомендованих нормами [3] $-65 \%$.

\section{ВИСНОВКИ}

1. Нелінійні закономірності розподілу експериментальних прогинів між балками свідчать про явно виражений просторовий характер роботи косих в плані широких прольотних будов при співвідношенні їх довжини до ширини між осями крайніх балок $L / B<2$, тобто про розподіл зусиль від тимчасових навантажень між балками як поперек, так і вздовж прольоту.

2. Малі прогини найбільш навантажених балок прольотних будов крайнього і середнього прольотів свідчать про значний запас вертикальної жорсткості балок і можливість сприйняття ними значно більших навантажень ніж досягнуті при випробуваннях. Загальний навантажувальний ефект найбільш навантажених балок від сумарних тимчасових і постійних навантажень становив (40$45) \%$ від їх несучої здатності, що менше від рекомендованого чинними нормами [3] - більше $65 \%$.

3. Випробування підтвердили можливість використання існуючих прольотних будов крайнього і середнього прольотів із демонтованими неремонтопридатними крайніми балками при реконструкції моста за умови їх підсилення зміною статичної схеми, ліквідації наявних дефектів і пошкоджень та повної заміни комплексу їздового полот- на і тротуарів. Існуючі прольотні будови мають також достатню несучу здатність для сприйняття технологічних навантажень під час виконання робіт із реконструкції шляхопроводу.

\section{БІБАІОГРАФІЧНИЙ СПИСОК}

1. Гибшман М.Б. Проектирование транспортных сооружений / М.Е. Гибшман, В.И. Попов. - М.: Транспорт, 1958. - 447 с.

2. Мости та труби. Основні вимоги проектування: ДБН В.2.3-22:2009. - [Чинні від 2010-03-01]. - Київ : ДП «Укрархбудінформ», 2009. - 73 с. - (Буд. норми України).

3. Мости та труби. Обстеження і випробування: ДБН В.2.3-6:2009. - [Чинні від 2010-03-01]. Київ: ВПВТД ВАТ ПТІ «Київоргбуд», 2009. - IV, 43 с. - (Буд. норми України).

4. Споруди транспорту. Настанова 3 оцінювання i прогнозування технічного стану автодорожніх мостів: ДСТУ Н Б В.2.3-23:2012. - [Чинний від 2013-12-01]. - Київ: ДП «Укрархбудінформ», 2012. - 54 с. - (Нац. стандарт України).

5. Кваша В.Г. Обстеження та випробування автодорожніх мостів / В.Г. Кваша // - Аьвів: НУ «Львівська політехніка», 2002. - 102 с.

6. Кваша В.Г. Аналіз розподілу тимчасового навантаження між балками прольотної будови за результатами натурних випробувань / В.Г. Кваша, В.С. Рачкевич // Вісн. Нац. ун-ту «入ьвівська політехніка» «Теорія і практика буд-ва». - Аьвів, 2008. - № 627. - С. 122-128.

7. Матаров И.А. Сборные железобетонные мосты с многорядной сварной арматурой / И.А. Матаров, А.С. Смирнова, А. А. Шилина. - М.: Автостройиздат, 1959. -186 с.

8. Рачкевич В.С. Розширення плитної нерозрізної збірно-монолітної залізобетонної прольотної будови косого в плані автодорожнього моста / В.С. Рачкевич, В.Г. Кваша, А.В. Салійчук // Вісн. Нац. ун-ту «Львівська політехніка» «Теорія і практика буд-ва». Аьвів, 2010. - № 664. - С. 156-163.

9. Розподіл тимчасового навантаження між балками бездіафрагмової прольотної будови моста за результатами натурних випробувань / [В.С. Рачкевич, В.Г. Кваша, А.В. Салійчук, А.А. Тузяк] // Вісн. Одеської держ. акад. будва і архітектури. - Одеса: ОДАБА, 2013. Вип. № 49, ч. 2. - С. 211-217.

10. Рачкевич B.С. Дослідження просторової роботи залізобетонної перехресно-ребристої балкової прольотної будови до та після розширення і підсилення накладною плитою / В.С. Рачкевич // Вісн. Нац. ун-ту «Львівська політехніка» «Теорія і практика буд-ва». Аьвів, 2015. - № 823. - С. 270-280. 


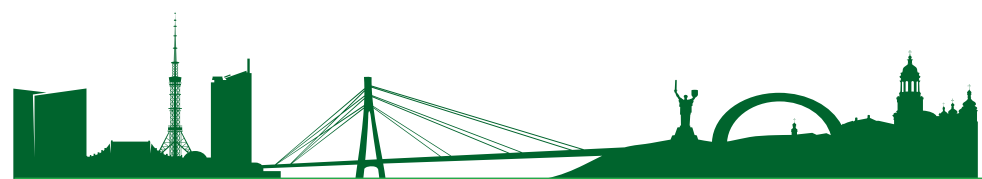

11. Рубаха М.В. Порівняльний аналіз розрахункових моделей плитної нерозрізної залізобетонної косої в плані прольотної будови до та після розширення накладною плитою / М.В. Рубаха, В.Г. Кваша, А.В. Салійчук // Вісн. Нац. ун-ту «Аьвівська політехніка» «Теорія і практика буд-ва». - Аьвів, 2011. № 697. - С. 199-210.

12. Типовые проекты сооружений на автомобильных дорогах. Вып. 56. Пролётные строения железобетонные, сборные с каркасной арматурой периодического профиля. - М.: Стройиздат, 1958. - 56 с.

13. Пространственные расчеты мостов / [Б.Е. УАицкий, А.А. Потапкин, В.И. Руденко и др.]. - М.: Транспорт, 1967. - 404 с.

Стаття надійшла до редакції 08.09.2017 року. 